\title{
Holocene non-orbital climatic events in present-day arid areas of northern Africa and China
}

\author{
Zhengtang Guo ${ }^{\text {a }}$, Nicole Petit-Maire ${ }^{\mathrm{b}}$, Stefan Kröpelin ${ }^{\mathrm{c}, *}$ \\ a Institute of Geology, Chinese Academy of Sciences, P.O. Box 9825, Beijing 100029, People's Republic of China \\ ${ }^{\mathrm{b}}$ MMSH / ESEP, Case 647, 13094 Aix-en-Provence, France \\ ${ }^{c}$ Cooperative Research Centre " ACACIA", Heinrich-Barth-Institut, University of Cologne, Jennerstr. 8, 50823 Cologne, Germany
}

\begin{abstract}
A preliminary comparison between the climatic evolution of the arid regions in northern Africa and northern China showed that the variations in continental aridity, on time scales of $10^{4}$ years, were roughly synchronous over the last $140 \mathrm{ka}$. Whether this relationship can be established for the Holocene drought events on a century-scale, as reported for tropical and equatorial Africa, is still not known. The comparison of 560 radiocarbon dates on surface fresh water indicators from the Sahara with 158 dates on palaeosols and lake sediments from the arid regions in northern China demonstrates that the Holocene humid phase has been affected in both regions by several drier events, inlaid in the slow trend attributable to orbital forcing. The variations of the southern margins of the deserts, associated with the northern monsoon front, are documented by the latitudinal distribution of these indicators through time. The most startling aspects are a prolonged somewhat drier interval between 7000 and 5600 years BP and the onset of severe aridity at c. 4000 years BP similar to glacial conditions. (C) 2000 Elsevier Science B.V. All rights reserved.
\end{abstract}

Keywords: Holocene; climate change; Sahara; radiocarbon; paleomonsoon; northern Africa; northern China

\section{Introduction}

Marine sediments in the North Atlantic and Greenland ice core records (Bond et al., 1993) indicate that rapid, high-amplitude climatic changes occurred during the Last Glacial period. Holocene instability has also been documented in several lacustrine sediments from arid, semi-arid and equatorial Africa, characterized by several century-scale drought intervals, which interrupted the generally wetter conditions of the Early and Mid-Holocene

\footnotetext{
* Corresponding author. Tel.: +49-221-955-9169; fax: +49221-550-2303.

E-mail address: s.kroe@uni-koeln.de (S. Kröpelin).
}

(Gillespie et al., 1983; Fabre and Petit-Maire, 1988; Street-Perrott and Perrott, 1990; Lamb et al., 1995). These droughts have been attributed to temporary weakenings of monsoon circulation, induced by changes in North Atlantic circulation, or to feedback processes stimulated by changes in tropical landsurface conditions (Lamb et al., 1995). Although similar oscillations have also been observed in western Asia (Gasse et al., 1991), considerable discrepancies in the timing and duration of these events still exist between the different localities.

The ways in which these abrupt events have affected the spatial extension of the Sahara desert and their impact on the mid-latitude deserts in Asia are still not well-known, but it is now possible to 
trace them through the large number of scattered data recorded in the literature.

\section{General framework, rationale and methods}

The Sahara and the deserts in northern China are among the most extensive arid areas in the Northern Hemisphere. The Sahara covers c. $9500000 \mathrm{~km}^{2}$, most of which is hyperarid. The boundary between the desert and its marginal, semi-arid transitional zones (the Sahel to the south and the Mediterranean zone to the north) roughly coincides with the 100$150 \mathrm{~mm}$ isohyets (Dubief, 1963). Modern annual rainfall in the Sahel is largely related to the East Atlantic summer monsoon circulation and to the migration of the meteorological equator, which seasonally oscillates between $4^{\circ} \mathrm{N}$ and $22^{\circ} \mathrm{N}$. In contrast, the area to the north receives scarcely any winter precipitation of North Atlantic origin (Lezine and Hooghiemstraa, 1990; Janicot and Fontaine, 1993). In China, desert lands occupy c. $1095000 \mathrm{~km}^{2}$, mainly within the $35-50^{\circ} \mathrm{N}$ latitudinal belt (Zhu, 1980). Annual rainfall is provided primarily by the Asian summer monsoon (Zhang and Lin, 1987).

In both regions, the Holocene contraction and extension of the deserts are documented by a limited number of continuous records and a large amount of scattered data (Zhu, 1980; Petit-Maire et al., 1993; Yan and Petit-Maire, 1994). In the currently arid regions, where palaeosols or lakes are not present under modern conditions, lacustrine/paludal sediments, shells of aquatic or terrestrial molluscs, bones of large aquatic or terrestrial reptiles and mammals, pollen and palaeosols, constitute the main natural evidence of more humid past conditions. The occurrence of fresh water bodies at the surface of a desert is related either to the outcropping of the phreatic nappes of the dune fields, to the rise of local or regional bodies at varied depths, or to the "pluviometer" effect of meteoric water falling into impervious closed depressions. The shallow (1 to $15 \mathrm{~m}$ ) paleolakes or swampy areas observed in the field are generally located in the interdune troughs of the ergs or in endoreic clayey areas, therefore implying a rapid response to non-incidental precipitation.

During the past few decades, many of these indicators have been radiocarbon dated throughout the regions under consideration, and a large number of dates have been accumulated. These data represent research conducted throughout the desert by several programmes.

A map of the Holocene palaeoenvironments has been published for the Sahara, based upon 1890 radiocarbon dates on geological and palaeobiological matter (Petit-Maire et al., 1993); 560 of these dates on surface fresh water indicators (lake and swamp sediments, fresh water shells, diatoms) are used in this report as the primary and most direct natural evidence of past humid climates. Of course not all of the dates observed in the continuous lake sequences have been considered: only one observation for a given time interval has been included to attest to the occurrence of surface water during that period. Some undated observations (prior to the past few decades) could not be considered, which therefore constitutes a bias. The number of these cases are limited and generally located in areas where much more numerous dated deposits are also listed.

Blank areas usually correspond to surfaces where the formation of lakes is not possible, i.e. due to geological environment, such as karstic plateaus through which rainwater can infiltrate.

Field work in the eastern and western Sahara between 1980 and 1990, led by two teams (Cooperative Research Project 69 "Arid Areas" and IGCP 252), searched the blank areas for deposits, but did not find anything significant in the prospected favorable areas, i.e. interdunes or clayey depressions with no possibility of infiltration (Fabre and Riser, personal communication; Kröpelin, unpublished data). Therefore, the frequency of recorded lakes and swamps, relative to the time scale, may be considered a valid representation of the evolution of humidity in the present-day hyperarid Sahara.

The number of ${ }^{14} \mathrm{C}$ dates on hydrological indicators available is relatively small for China. In the present-day deserts, however, several Holocene palaeosols, usually intercalated within aeolian beds, were discovered and dated. Only 158 published ${ }^{14} \mathrm{C}$ dates on palaeosols and surface water sediments could be culled from the literature of the last 10 years. Their frequency, as shown in Fig. 2, is of course significantly less representative than the data from the in-depth field research in the Sahara, and is clearly biased based on geographical choices. There- 
fore, the curve for China must be considered with great caution. The comparison presented in this paper, however, complies with the expected relationship between African and Asian monsoonal patterns (Kutzbach and Otto-Bliesner, 1982; Kutzbach, 1987).

The frequencies of the considered markers have been calculated at a 400-year interval and expressed as percentages of the total number for each area. They are plotted against the BP ages in Figs. 1 and 2. The broad interval was selected to eliminate statistical error on the ages and variance between different samples linked to the quality of the carbon although these are negligible in the case of the material listed above, which yields high quality and comparable results (Delibrias et al., 1991). Based on the comparison of the frequencies in China and northern Africa, this paper seeks to determine whether the non-orbital climatic events in both regions were teleconnected over the Holocene. The latitudinal distribution pat-

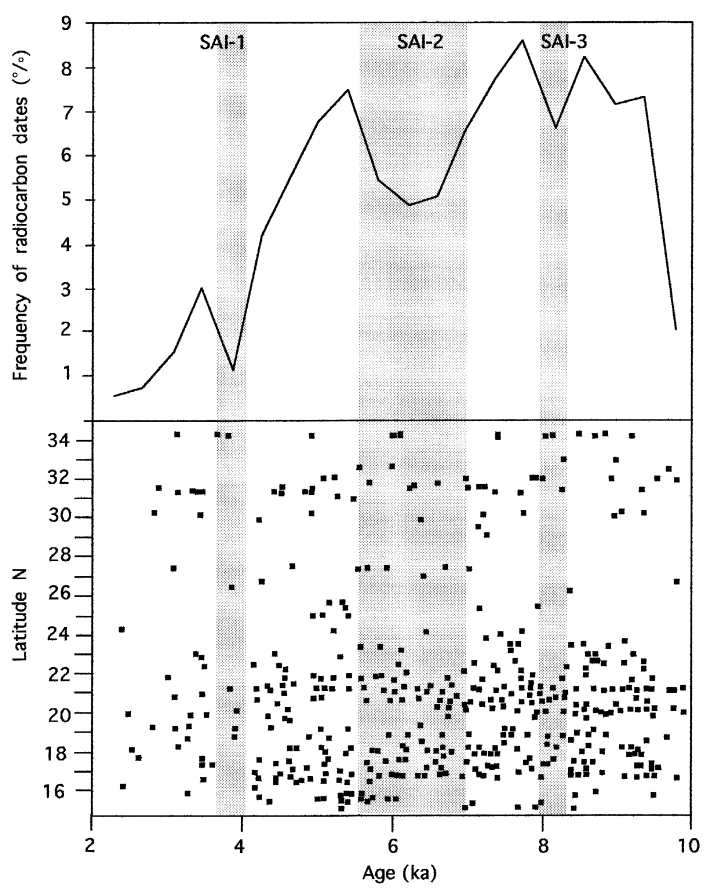

Fig. 1. Temporal and latitudinal distribution of the surface fresh water indicators from the Sahara. (a) Age frequency of the radiocarbon dated markers. The frequencies are calculated at 400-year intervals and expressed as a percentage of the total number (560 dates). The drier episodes are marked by shaded zones. (b) Latitudinal distribution of the dated markers

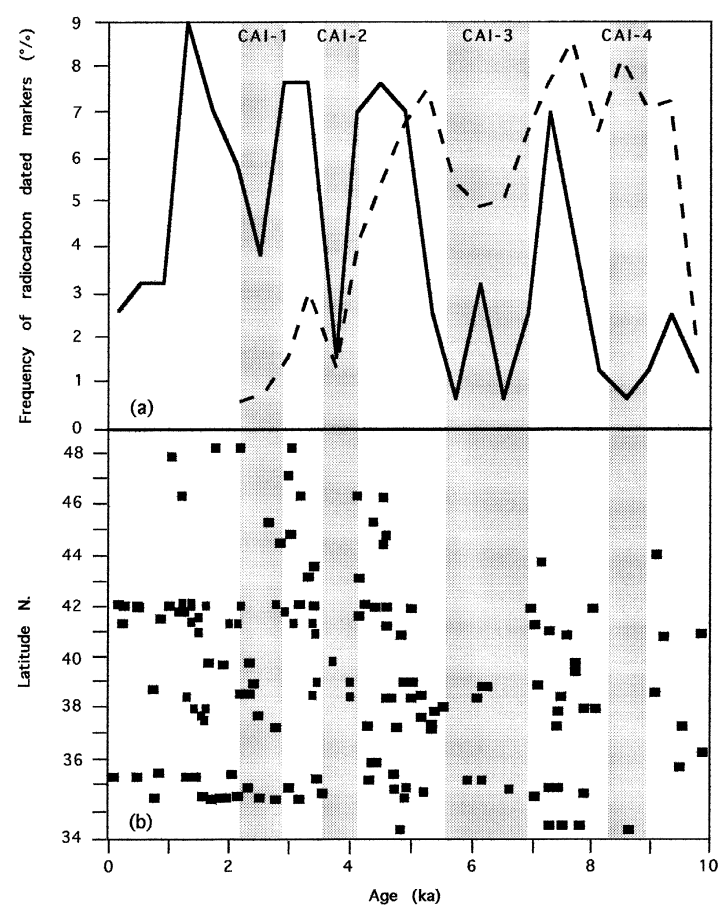

Fig. 2. Temporal and latitudinal distribution of humid indicators (palaeosols and lacustrine sediments) from the deserts in northern China. (a) Age frequency of the radiocarbon dated markers (continuous line) compared with that of the Sahara (dotted line). The frequencies are calculated at 400-year intervals and expressed as a percentage of the total number (158 dates). The drier episodes are marked by shaded zones. (b) Latitudinal distribution of the dated markers.

tern of the data and the frequency relative to time are compared with the results of some geological records.

\section{Results}

\subsection{Climatic events in the Sahara}

The temporal distribution of the ${ }^{14} \mathrm{C}$ dates for the Sahara is shown in Fig. 1a. A large increase in the amount of humid indicators began at $9.5 \mathrm{ka}$ and progressively decreased after $5 \mathrm{ka}$. This slow trend is consistent with the strengthening and weakening of the monsoon circulation, in response to the changes in summer insolation over the Northern Hemisphere (Kutzbach and Street-Perrott, 1985). The humid phase is marked, however, by two slightly drier 
intervals - a short one (SAI-3) around $8 \mathrm{ka}$ and a longer one (SAI-2) between c. 7 and $5.7 \mathrm{ka}$. Extreme aridity, similar to the one prior to $10 \mathrm{ka}$, is reached at c. 4 ka (SAI-1). (A few data form a slight peak around $3 \mathrm{ka}$, which is not significant since the markers are located near the Atlantic coast). SAI-3 lasted for about 3 centuries, SAI-2 more than a millennium.

When considering the latitudinal distribution of the data (Fig. 1b), the density is noticeably greater in the southern part, up to c. $23^{\circ} \mathrm{N}$. From c. $24^{\circ} \mathrm{N}$ to c. $30^{\circ} \mathrm{N}$, the data are extremely scarce during the entire Holocene. The density increases again from $30^{\circ} \mathrm{N}$ to the north. This spatial pattern is unlikely to be explained by topographic features, as the latitudinal variations of the Saharan topography are rather monotone when compared with the longitudinal changes. The interpretation that the high density of surface fresh water bodies in the southern Sahara is related to monsoonal precipitation, and the data from the northern area is related to Mediterranean rainfall, corresponds to the atmospheric circulation pattern which now prevails over northern Africa. Nearly all of the infrequent bodies of water between $25^{\circ} \mathrm{N}$ and $29^{\circ} \mathrm{N}$ are located in the highlands (Hoggar, Tibesti), or associated with wadis running from the massifs into the basin (Petit-Maire et al., 1993).

The chronological oscillations of the data limit in Fig. 1b should reflect the fluctuations of the meteorological equator, currently characterized by its instability across northern Africa (Janicot and Fontaine, 1993). The latitudinal range of the data limit complies with the results of its Holocene modeled variations (Bryson, 1992), and implies that our sample may be considered valid (otherwise the distribution should be independent of their time frequency).

\subsection{Climatic events in northern China}

The temporal and spatial distribution of the ${ }^{14} \mathrm{C}$ dates from the arid regions in northern China are shown in Fig. 2. Since annual rainfall in the region is closely related to the range of the summer monsoon (Zhang and Lin, 1987), the latitudinal fluctuations of the desert margin should be associated with the oscillations of the northern monsoon range. Three drier intervals occur at around $8.5 \mathrm{ka}$ (CAI-4), and between 7 and $5.6 \mathrm{ka}$ (CAI-3), and around $4 \mathrm{ka}$ (CAI-2, Fig. 2). It is difficult to compare the Chinese data for more recent periods with the previously mentioned frequencies, since they correspond to historical periods with numerous data from the archives.

\subsection{Comparison of climatic events in the Sahara and northern China}

CAI-4, CAI-3 and CAI-2 correspond to Saharan events (Fig. 2a), although the timing for the Chinese events lags slightly behind those of the Sahara. Since most of the data for China is from palaeosols, the reason why the Chinese events are not synchronous with the Saharan events may be explained by the delayed response of the palaeosols due to pedogenesis duration after onset of rainfall and the subsequent development of a vegetative cover. Otherwise, the number of radiocarbon dates, especially for the early Holocene, is probably too small to reflect the real amplitudes of climatic changes: this applies both to the short, less dry episode centered at about $6.2 \mathrm{ka}$ within the generally drier CAI-3 interval, which has no signal in Sahara, as well as to the short event just before $8 \mathrm{ka}$.

\section{Discussion}

The deserts in northern Africa and northern China have therefore both recorded short-scale events, on time scales of centuries to one millennium. In both cases, the spatial variations of the data document changes in the location of the southern margins of the deserts, which are associated with the summer monsoons.

The conditions during the first drier episodes in the Sahara were only slightly drier than those during the optima. In both regions there is a corresponding abrupt decrease of the data frequency after $5 \mathrm{ka}$, which ended with extreme aridity at $4 \mathrm{ka}$. The amplitude of climatic changes seems to be much greater in China than in the Sahara, which corresponds with global latitudinal trends during the glacial-interglacial cycles (COHMAP Members, 1988).

In Africa, century-scale Holocene dry episodes have already been reported from a number of lacustrine records (Gillespie et al., 1983; Fabre and PetitMaire, 1988; Street-Perrott and Perrott, 1990; Lamb 
et al., 1995). Considerable discrepancies still exist, however, in the number, timing and duration of the events, probably due to regional factors, resolution of the sediment cores, and/or ambiguities in the proxy data. The dry interval recorded here at c. 8.2 $\mathrm{ka}$, correlates with the interval from the Bosumtwi lake record (Ghana, Talbot et al., 1984) and the organic matter record from Mt. Satima Mire, Kenya (Street-Perrott and Perrott, 1990). The dry interval at c. 7-5.7 ka fits continuous palaeolacustrine records in the western Sahara, near $23^{\circ} \mathrm{N}$ (Fabre and PetitMaire, 1988; Oxnevad, 1991; Fabre, 1991): the comprehensive study on the Agorgott saline paleolake revealed hydrological deterioration, characterized by a sharp increase in salinity and extensive halite deposition, occurring between 6.7 and $5.6 \mathrm{ka}$. In the carbonate paleolake Haijad, a low lake level event dated at c. $6.7 \mathrm{ka}$ is indicated by a mud-crack layer and followed by a marked decrease of the sedimentation rate. It is worth noting that Servant and Servant-Vildary (1980) records a very dry episode in Chad around $7.5 \mathrm{ka}$. The c. 4 ka dry episode has been identified throughout Africa (Street-Perrott and Perrott, 1990; Lamb et al., 1995). In the Saharan lowlands, all of the lakes have dried up and will not be fed again (Fabre and Petit-Maire, 1988; Kröpelin 1989; Pachur and Kröpelin, 1989; Petit-Maire, 1989; Pachur et al., 1990; Fabre, 1991; Kröpelin, 1993).

In China, dry climatic conditions tend to be associated with cooling events (Shi et al., 1993; Van Campo and Gasse, 1993). The Holocene drier episodes reported here are consistent with the dry and/or cooling events reported from several other records. A high-resolution ice core record (Yao and Shi, 1992) from the Qilian mountains, which is not comparable since the site is more than $5325 \mathrm{~m}$ high, reveals a severe cooling event from 8.9 to 8.6 calendar years, and thus precedes the CAI- 4 dry episode in this report. A well-dated pollen record (Liu, 1989) in northern China records drier/cooler episodes at 8.9-8.2, 7.5-5.4, 4-3.5 and 3-2 ka, characterized by a decrease in the annual pollen flux and the number of wooden and shrub assemblages, which corresponds with the results of this report. A dry and cooler episode is also recorded after $7 \mathrm{ka}$ in a pollen record of Hainan Island in southernmost China ( $\mathrm{Li}$ et al., 1991). In the Yangtze River Basin, a well-dated, high-resolution pollen record clearly records a Mid-
Holocene arid/cooling interval from 7.5 to $6 \mathrm{ka}$, as indicated by a large increase in the content of Pinus and a decrease in that of Castanea and Quercus (Tang and Shen, 1992). During this interval, thick evaporitic salt was deposited in the Qaidum Basin (Shi et al., 1993). The c. 4 ka dry interval has been reported throughout China, based on ice-core records (Yao and Shi, 1992), pollen records (Li et al., 1991; Tang and Shen, 1992), and archaeological evidence (Shi, 1992).

The evidence of drier climatic conditions in China at the time around $6 \mathrm{ka}$ was thought to be related to higher temperatures resulting in stronger evapotranspiration (Shi et al., 1993). The fact that the drier events are clearly expressed in lower latitude Sahara does not support this interpretation, since the Holocene Optimum changes at lower latitudes were largely insignificant (COHMAP Members, 1988). Consequently, these dry episodes must be related to a general weakening of the monsoons, which coincides with suggestions made in previous studies on Africa (Petit-Maire, 1986; Street-Perrott and Perrott, 1990; Lamb et al., 1995).

Although most authors tend to consider the MidHolocene (i.e., Shi et al., 1993) as the Climatic Optimum, the consistency between the frequencies of the data, their latitudinal distribution and other palaeobiological evidence such as pollen or large mammals, in both China and the Sahara, indicates that a dry interval did occur around $6 \mathrm{ka}$ BP.

The non-orbital arid intervals recorded in the Chinese loess of the last glacial period are thought to be related to the North Atlantic Heinrich events (Porter and An, 1995) and changes in the North Atlantic thermohaline circulation. Changes in the North Atlantic Deep Water (NADW) have also been proposed as a means of explaining fluctuations of the Holocene African monsoon (Street-Perrott and Perrott, 1990). The timing and the duration of the dry intervals reported here suggest, however, that the changes in NADW strength cannot explain all of the episodes with weakened monsoon.

It is remarkable that, in spite of the imperfections of our samples, the drier interval around $6 \mathrm{ka}$ corresponds to a period of lowered SSTs in the China Sea (Wang et al., 1995) and to the end of a humid episode over the Sea of Arabia (Sirocko et al., 1993). The validity of our synthesis is confirmed by the 
similarities to oceanic patterns. Future additional observations, with better temporal and spatial resolutions, should serve to confirm our results.

\section{Acknowledgements}

This work is part of the IUGS-UNESCO Programme "Climates of the Past" (CLIP), the National Natural Science Foundation of China, and the CNRS-Chinese Academy of Sciences exchange convention. Z.T. Guo warmly thanks J.L. de Beaulieu for hosting him at his Marseilles laboratory, J. Guiot for his helpful suggestions, and Professor Liu Tungsheng for his support.

\section{References}

Bond, G., Broecker, W., Johnson, S., McManus, J., Labeyrie, L., Jouzel, J., Bonanl, G., 1993. Correlations between climate records from North Atlantic sediments and Greenland ice. Nature 365, 143-147.

Bryson, R.A., 1992. A macrophysical model of the Holocene Intertropical Convergence and Jetstream positions and rainfall for the Saharan region. Meteorol. Atmos. Phys. 47, 247-258.

COHMAP Members, 1988. Climate changes of the last 18.000 years: observations and model simulations. Science 241, 1043-1052.

Delibrias, G., Fontugne, M., Arnold, M., 1991. Datations par le ${ }^{14}$ C. In: Petit-Maire, N. (Ed.), Paléoenvironnements du Sahara. CNRS, Marseille-Paris, France, pp. 177-180.

Dubief, J., 1963. Le Climat du Sahara. Travaux de l'Institut de Recherches Sahariennes, Alger. Tome 1: 312 pp. et Tome 2: 275 pp.

Fabre, J., 1991. Cadre géologique et évolution. In: Petit-Maire, N. (Ed.), Paléoenvironnements du Sahara. CNRS, Marseille-Paris, France, pp. 81-90.

Fabre, J., Petit-Maire, N., 1988. Holocene climatic evolution at $22^{\circ}-23^{\circ} \mathrm{N}$ from two palaeolakes in the Taoudenni area (northern Mali). Palaeogeogr., Palaeoclimatol., Palaeoecol. 65, 133 148.

Gasse, F., Arnold, M., Fontes, J.Ch., Fort, M., Gibert, E., Huc, A., Li, B.Y., Li, Y.F., Liu, Q., Melieres, F., Van Campo, E., Wang, F.B., Zhang, Q.S., 1991. A 13.000-year climate record from western Tibet. Nature 353, 742-745.

Gillespie, R., Street-Perrott, F.A., Switsur, R., 1983. Post-glacial arid episodes in Ethiopia have implications for climate prediction. Nature 306, 680-683.

Janicot, S., Fontaine, B., 1993. L'évolution des idées sur la variabilité interannuelle récente des précipitations en Afrique de l'Ouest. Météorologie 8 (1), 28-53.

Kröpelin, S., 1989. Untersuchungen zum Sedimentationsmilieu von Playas im Gilf Kebir (Südwest-Ägypten). Forschungen zur Umweltgeschichte der Ostsahara. Heinrich-Barth-Institut, Cologne, pp. 183-306.

Kröpelin, S., 1993. Zur Rekonstruktion der spätquartären Umwelt am Unteren Wadi Howar. Berl. Geogr. Abh. 54, 293 p.

Kutzbach, J., 1987. The changing pulse of the Monsoon. In: Fein, J., Stephens, P. (Eds.), Monsoons. Wiley, pp. 247-268.

Kutzbach, J.E., Otto-Bliesner, B.L., 1982. The sensitivity of the African-Asian monsoonal climate to orbital parameters changes for 9000 years BP in a low-resolution general circulation model. J. Atmos. Sci. 39 (6), 1177-1188.

Kutzbach, J.E., Street-Perrott, F.A., 1985. Milankovitch forcing of fluctuations in the level of tropical lakes from 18 to $0 \mathrm{Kyr}$ BP. Nature 317, 130-134.

Lamb, H.F., Gasse, F., Benkaddour, A., El Hamouti, N., Van der Kaars, S., Perkins, W.T., Pearce, N.J., Roberts, C.N., 1995. Relation between century-scale Holocene arid intervals in the tropical and temperate zones. Nature 373, 134-137.

Lezine, A.M., Hooghiemstraa, H., 1990. Land-sea comparisons during the last glacial-interglacial transition: pollen records from West Tropical Africa. Palaeogeogr., Palaeoclimatol., Palaeoecol. 79, 331-331.

Li, P.R., Zheng, J.S., Fang, G.X., 1991. Quaternary Geology in the Guangzhou Region. Press of Guangzhou Science and Technology University, 180 pp. (in Chinese, with English abstract).

Liu, J.L., 1989. Vegetation and climatic changes over the last 13.000 years in the Gushan marshlands, Changbeishan region. Palaeontol. Sin. 28, 495-511, (in Chinese, with English abstract).

Oxnevad, I., 1991. Sédimentologie du paléolac. In: Petit-Maire, N. (Ed.), Paléoenvironnements du Sahara. CNRS, Marseille-Paris, France, pp. 131-140.

Pachur, H.J., Kröpelin, S., 1989. L'aridification du Sahara oriental à l'Holocène supérieur. Bull. S. G. F. 8, 99-107.

Pachur, H.J., Kröpelin, S., Hoelzmann, P., Goshin, M., Altmann, N., 1990. Late quaternary fluvio-lacustrine environments of Western Nubia. Berl. Geowiss. Abh., Reihe A, 120 pp.

Petit-Maire, N., 1986. Palaeoclimates in the Sahara of Mali: a multidisciplinary study. Episodes 9, 7-16.

Petit-Maire, N., 1989. Interglacial environments in the presently hyperarid Sahara: paleoclimatic implications. In: Leinen, M., Sarnthein, M. (Eds.), Paleoclimatology and Paleometeorology: Modern and Past Patterns of Global Atmospheric Transport. Kluwer Academic Publishing, Netherlands, pp. 637-661.

Petit-Maire, N., Page, N., Marchand, J., 1993. The Sahara in the Holocene. Map 1/5.000.000. UNESCO-CGMW, Paris, France.

Porter, S.C., An, Z., 1995. Correlation between climate events in the North Atlantic and China during the last glaciation. Nature 375, 305-308.

Servant, M., Servant-Vildary, S., 1980. L'environnement quaternaire du bassin du Tchad. In: Williams, M.A.J, Faure, H. (Eds.), The Sahara and the Nile. Balkema, Rotterdam, pp. 133-162.

Sirocko, F., Sarnthein, M., Erlenkeuser, H., Lange, H., Arnold, M., Duplessy, J.C., 1993. Century scale events in monsoonal climate over the past 24 OOO years. Nature 364, 322-324. 
Shi, S.H., 1992. The impact of climatic changes during Holocene Megathermal on the Neolithic culture in China. The Climates and Environments of Holocene Megathermal in China. China Ocean Press, Beijing, pp. 185-191, (in Chinese).

Shi, Y.F., Kong, Z.C., Wang, S.M., Tang, L.Y., Wang, F.B., Yao, T.D., Zhao, X.T., Zhang, P.Y., Shi, S.H., 1993. Mid-Holocene climates and environments in China. Global Planet. Change 7, 219-233.

Street-Perrott, F.A., Perrott, R.A., 1990. Abrupt climate fluctuations in the tropics: the influence of Atlantic Ocean circulation. Nature 343, 607-612.

Talbot, M.R., Livingstone, D.A., Palmer, P.G., Maley, J., Melack, J.M., Delibrias, G., Gulliksen, S., 1984. Preliminary results from sediment cores from Lake Bosumtwi, Ghana. Paleoecol. Afr. 16, 173-192.

Tang, L.Y., Shen, C.M., 1992. The vegetation and climate of Holocene megathermal in northern Jiangsu Province. In: Shi, Y.F., Kong, Z.C. (Eds.), The Climates and Environments of Holocene Megathermal in China. China Ocean Press, Beijing, pp. 80-93, (in Chinese).
Van Campo, E., Gasse, F., 1993. Pollen and diatom inferred climatic and hydrological changes in Sumxi Co Basin (Western Tibet) since 13000 yrs BP. Quat. Res. 39, 300-313.

Wang, L., Pflaumann, U., Sarnthein, M., 1995. A first high resolution sediment record of climatic change in the South China Sea during the last 30000 years. Terra Nostra INQUAFUB, Berlin, p. 292.

Yan, Z.W., Petit-Maire, N., 1994. The last $140 \mathrm{ka}$ in the AfroAsian arid/semi-arid transitional zone. Palaeogeogr., Palaeoclimatol., Palaeoecol. 110, 217-233.

Yao, T.D., Shi, Y.F., 1992. Climatic changes of Holocene reflected in the ice core from Dunde, Qilian Mountains. In: Shi, Y.F., Kong, Z.C. (Eds.), The Climates and Environments of Holocene Megathermal in China. China Ocean Press, Beijing, pp. 206-211, (in Chinese).

Zhang, J.C., Lin, Z.G., 1987. Climate in China. Meteorology Press, Beijing, 325 pp. (in Chinese).

Zhu, Z.D., 1980. Desert lands in China. Science Press, Beijing, 280 pp. (in Chinese). 